\title{
Putting ideas into action
}

\author{
Alumni duo nurture and educate children in Cambodia's Aziza's Place \\ By Jacquelyn Walsh ('og)
}

magine not being able to afford to feed or care for your own children.

JMU alums Alexandra Robbins ('07) and Daniel Haney ('07) are fixing this problem 9,000 miles around the globe in Cambodia. The duo has taken the JMU "Be the Change" spirit to Aziza's Place, a learning center for impoverished children. As interim directors, Robbins and Haney give kids a place to live as well as a free education. They also keep the children's family connections intact. The children are not orphans; their families work in the municipal dumpsite picking up trash for less than $\$ 2$ per day.

"This lifestyle is a hazardous and difficult one for the families," says Robbins. "Most of the children we took in were at one time garbage pickers themselves."

The children's family members come monthly to visit at Aziza's Place, and the children go to visit them at home weekly, add Robbins and Haney, who also started a community outreach program to connect families with free resources, and employ family members at Aziza's Place whenever possible.

Robbins and Haney provide 21 children with a public school education through the Cambodian system as well as supplemental classes in their native language Khmer. The students also learn mathematics, computer skills and English. Extracurricular activities include karate, soccer, film, art, traditional Khmer dance and music.

"Since we have only 21 children it makes our program very unique and structured. We give each child the nurturing and opportunities they deserve," says Robbins, a Reston, Va., native.

\section{'We give each child the nurturing and opportunities they deserve. We get to put ideas into action.'}

- Alexandra Robbins ('o7)

Aziza's Place director
The children range in age from 6 to 18 . "Usually a child comes to Aziza's Place at age 6 or 7 , and this way the children get a lot of one-on-one interaction as they grow up here."

Next year Aziza's Place will have its first high-school graduate, who is "more than ready for college," says Haney. The students also start summer

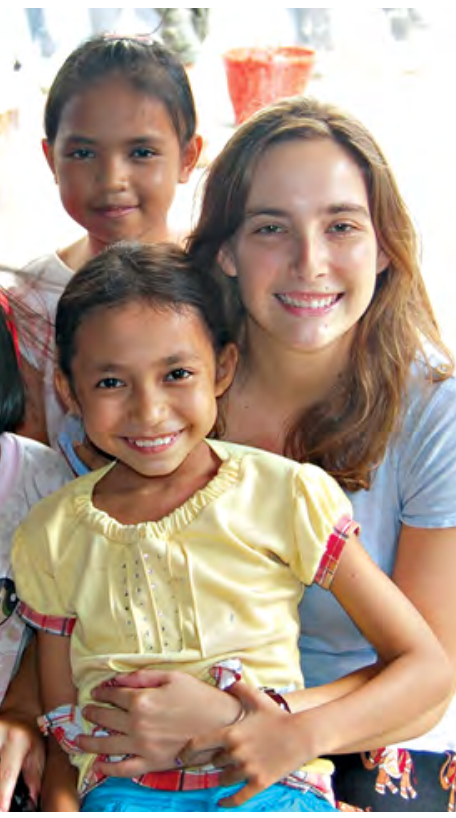

internships at local businesses, which is important for them to get real-world experience, he adds.

Robbins, a political science graduate, and Haney, a geographic science graduate, both lived in Hillside Residence Hall as freshmen. They reconnected during their senior year in an offcampus housing complex, Madison Terrace, and then began dating.

When Robbins graduated, she considered joining the Peace Corps but a family friend, who started the foundation for Aziza's Place, suggested she work there. Robbins traveled to Cambodia in September 2007 and Haney followed three months later. "We get to put our ideas into action," says Robbins. "This unique kind of serving opportunity is rare in America."

As an undergraduate, Robbins hosted a radio show on WXJM and started a chapter of the National Organization for Women, which became an official club during her senior year. She also participated in the Washington Semester program, a semester-long internship in the Metro-D.C. area.

Haney, a member of the varsity rugby team at JMU, got a taste of Study Abroad when he traveled to the Philippines in May 2006 through a JMU program with Jonathan Walker, an integrated science and technology professor. "You try to interpret what your teacher is teaching through books in class, but nothing compares to getting to experience it in the world," says Haney of Boyce, Va.

Haney was a member of the adventure club and enjoyed rock climbing and working out at UREC's climbing wall.

Robbins and Haney hope the native Cambodians will be able to take over direction of Aziza's Place in the coming year. "There are still business, finance and marketing aspects that have to be done," says Haney, "but we have all but one of the staff prepared - a difficult task because most of the population of Cambodia is uneducated." With five administrative staff and 10 other staff members the Aziza's Place team has become "a very close-knit family," adds Robbins.

After they return to the states, Robbins and Haney will continue to be a part of Aziza's Place as board members. mlt * Learn more about this JMU duo's work at www.azizafoundation. org/projects.html. 